\title{
Review
}

\section{Some People and Places Important in the History of Analytical Chemistry in Romania**}

\author{
RALUCA-IOANA STEFAN-VAN STADEN ${ }^{1 *}$, VICTOR DAVID², \\ DUNCAN THORBURN BURNS ${ }^{3}$ \\ ${ }^{1}$ National Institute of Research for Electrochemistry and Condensed Matter, Laboratory of Electrochemistry and PATLAB, \\ 202 Splaiul Independentei, 060021, Bucharest, Romania \\ ${ }^{2}$ University of Bucharest, Faculty of Chemistry, Department of Analytical Chemistry, 4-12 Regina Elisabeta Blvd., 040121, \\ Bucharest, Romania \\ ${ }^{3}$ The Queen's University of Belfast, Institute of Global Food Security, Belfast, BT9 5AG, UK
}

Abstract: Analytical chemistry developed from alchemical origins in the 14th century becoming more scientific in nature from the late 17th century and continues to thrive in modern Romania, as in the rest of Europe.

Keywords: Analytical Chemistry, History, Romanian Analytical Chemists

\section{Geographic and locational problems with inclusions}

Analytical Chemistry as science and discipline has very old routes in Romania. Many Romanian analytical chemists with international reputations have carried out research in Romania, whilst others have used abroad the high level of skills and knowledge gained during their studies in Romania. To produce an account of the people and places that are important in the history of analytical chemistry in Romania has posed similar problems to those encountered when producing an equivalent account for Germany [1]. These are the definition of the land area to regard as pertinent, the inclusion or otherwise of expatriates, such as Nicolae Teclu (1839-1916) [2], whose main work was carried out outside Romania, as defined herein. Further problems arise when dealing with the early period due to the lack of written documents on the activities of potters, smiths and other metalworkers whose activities required empirical chemical knowledge, as noted by Popa [3]. Analysis of these early products have given impetus to modern trace element studies [4-6]. Problems exist with the identity of residents in the Middle Ages in areas such as Transylvania [7]. Later on in time the developments in the fields of inorganic, organic and analytical chemistry growing, together created a huge community from within and without Romania from whom to pick who did pioneering work in the field of analytical chemistry.

\section{From Alchemy to the beginning of scientific chemistry}

The rise of a mystical type of alchemy including the supposed transmutation of metals and early chemical theories that incorporated some aspects of Christian theology are detectable in many alchemical writings from the 14th century onwards. These became more extensive in the work of Nicolaus Melchior Cibinensis who composed an alchemical mass, Processus sub form missae [8]. The structure of the text has been recently analysed and a tentative identity assigned to the author, as a member of a family of goldsmiths of Cibino, Transylvania [9]. A representation of Melchior Cibinenfis Vngarus was shown in Maier's, Symbola aurae mensae [10], (Figure 1). The designation Hungarian for a resident of Cibano, Sibiu in modern Romania, illustrates the problems of location and nationality for the present review.

The next alchemist of interest is János Bánfi-Hunyadi (1576-1646) or Johannes Banfi Hunyades as he was known in England, who arrived in London about 1616. Various versions of his portrait exist, (Figure 2) [11].

*email: ralucavanstaden@gmail.com
** This paper is the result of the work of the Study Group History from the Division of Analytical Chemistry of EuChemS 
As far as known he never published any alchemical or scientific texts or left a substantial amount of correspondence, much about his career can be learned from published reports of his contemporaries and from unpublished manuscript collections [11-15]. From around 1625, he was Kenelm Digby's chemical operator at Gresham College, London and was associated with the well-known alchemist Arthur Dee [13].

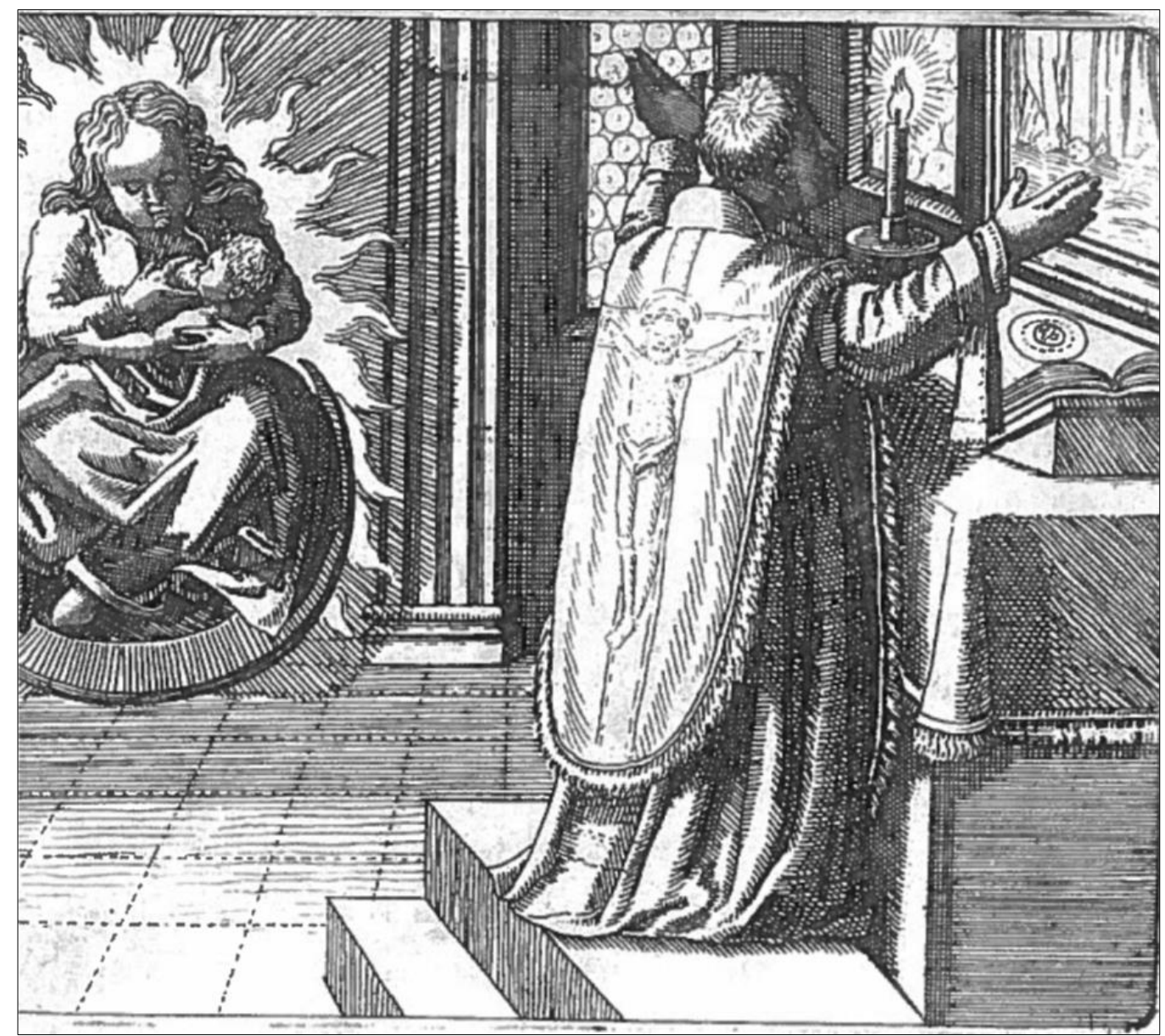

Figure 1. Representation of Melchior Cibinenfis Vngarus [10]

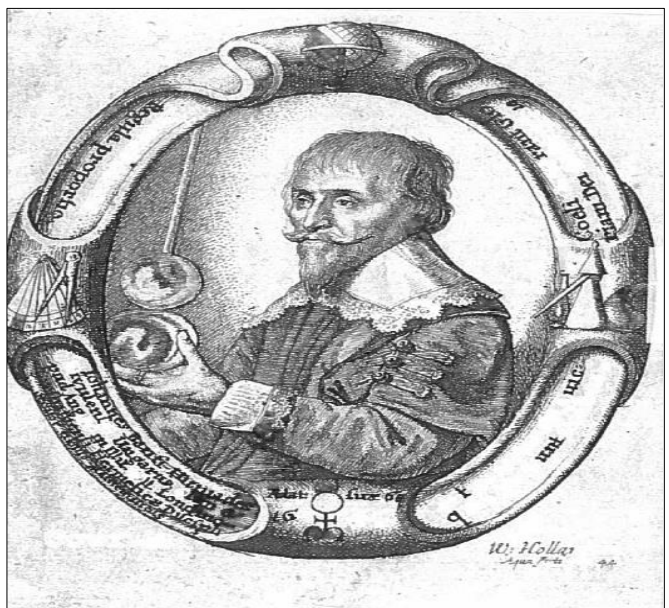

Figure 2. Portrait of Johannes Banfi Huniades, W. Hollarfecit, 1644 [11] 
At the beginning of 18th century, Dimitrie Cantemir (Ioanis Dimitrios Constantini Kantemir Princeps Terrarum Moldaviae) in his book "Compendium universae logices institutiones" wrote about chemistry, namely elements, water and air in detail [16].

The Royal Society of London published in Philosophical Transactions, a series of Inquires for travellers to foreign parts to collect up information for their Fellows. Two of the inquiries were directed specifically to the care of Dr. Edward Brown, F.R.S., both reports referred to vitriol and the salt pits of Transylvania $[17,18]$. Some of the replies were sent to Henry Oldenburg, the Secretary of the Royal Society, others directly to individual members of the Royal Society, for example the letters by Bishop Burnett to Robert Boyle [19]. The continued interest in London in minerals and mines is illustrated by the large collection of Carpathian minerals made by John Woodward (1665-1728) in the late seventeenth to early eighteenth century [20].

Johannes Brün (1608-?) also known as Van Mussig or Unmussig, is another alchemist, resident in London in the late 1640s and early 1650s. He was at one time a medical advisor to Lady Ranelagh, Robert Boyle's sister, and is traceable via his correspondence and that of Samuel Hartlib [21, 22] who with Robert Boyle were both members of "The Invisible College", the precursor to the Royal Society [23]. Brün was for a time an alchemist in the service of Prince G. Rákóczy, of Transylvania.

Samuel Köleseri (1663-1732) was chief physician of Transylvania and supervisor of the mines there [15]. He published widely on a great variety of topics. His Auraria Romano- Daccia [24] describing the Transylvanian gold mining locations, processes and uses to which the metal was put, had a lasting value, it contains his portrait, (Figure 3). He was elected, the first Transylvanian, Fellow of the Royal Society in 1732, being proposed by Sir Hans Sloane, John Machin and William Rutty [25].

Frenchman Georges Flachat established the first analytical laboratories for the control of metal quality in Transylvania (e.g., monetary gold titre) in 1830 [3].

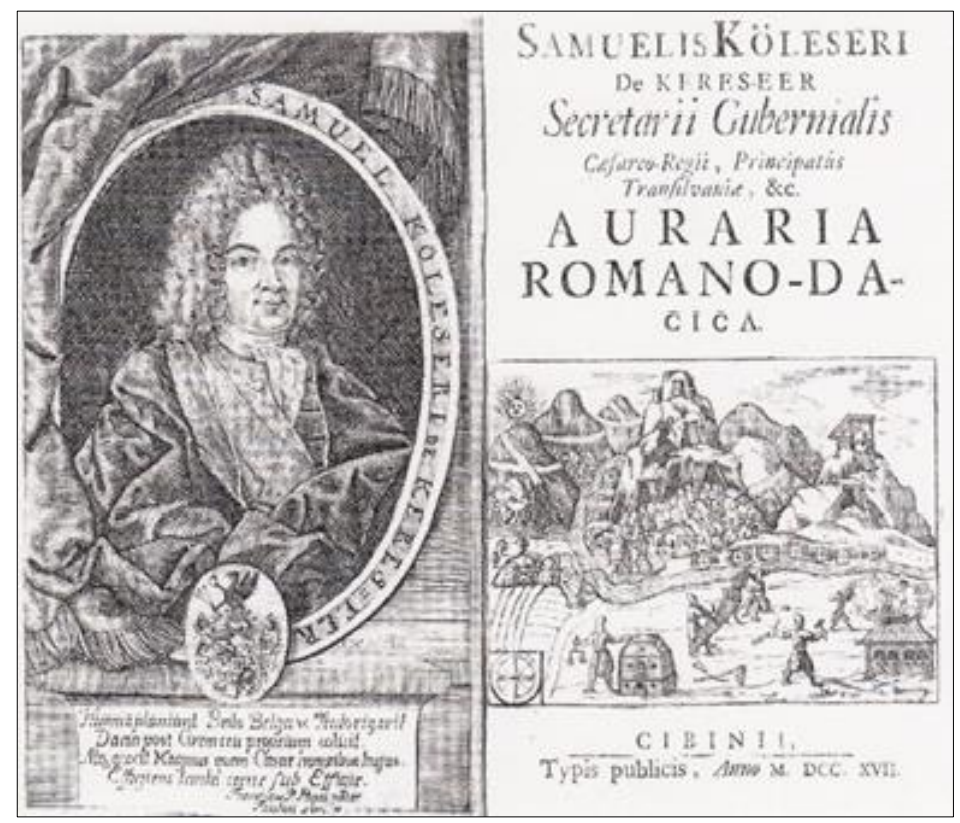

Figure 3. Portrait of Samuel Koleseri and title page Auraria Romano-Daccia, 1717 [24]

Franz Joseph Müller von Reichenstein (1742-1825), from Sibiu, discovered a new chemical element in the minerals from Zlatna (Transylvania), which he called "aurum paradoxium" or "metallum problematicum". In 1782, Martin Heinrich Klaproth, in Berlin, who called this new element Tellurium [26], confirmed Müller's discovery. 


\section{Development as a scientific discipline in the nineteenth century}

Baiulescu has reviewed the development of analytical chemistry in Romania from the start of the 19th century [27]. The Society of Physicians and Naturalists in Moldavia founded in 1833 [28] and represents, as Popa emphasized [3], an outstanding moment in the development of Analytical Chemistry. In 1824, studies on mineral water analysis performed by Zotta Gihoc and his collaborators appeared in a magazine called "Albina Romaneasca"; and republished later, in 1839 in Buchner's Chemische Annalen.

In 1835, the first higher school was founded in Moldova, at Jassy, courses on chemistry and experimental practice were included in the curricula [3]. In Bucharest, Carol Davila the founder of the Higher School of Medicine and Pharmacy followed by Alfred Bernath (an Austrian) who in 1855 introduced into the curricula experiments on foodstuffs and drug adulteration and the first laboratories on analysis of foodstuff, drinks, forensic, and medical analysis were established [3]. Furthermore, in 1893, at the Higher School of Medicine and Pharmacy the first department focussed on analytical chemistry, called "department of chemistry and analysis of foodstuffs and beverages". The laboratory, which was in 1897 taken over by Stefan Minovici, the first professor of Analytical Chemistry [30]. Minovici, in time, became well known for his methods for the determination of potassium, picric acid and manganese.

Outstanding contributions to the development of Analytical Chemistry in Romania since the foundation of Universities in Jassy (1860) and in Bucharest (1864) were made by two Romanian chemists: Petru Poni (1878, Chair of Chemistry Department in Jassy) and Constantin C. Istrati (1887, Chair of the Analytical Chemistry Department in Bucharest). Petru Poni made studies on mineral water analyses, investigations of the minerals in the crystalline massif of Brosteni, and determination of the composition of crude oil. Istrati also investigated the natural resources of Romania: salt, ozokerite, amber, and oil [3].

N. Costachescu and Radu Cernatescu from Jassy University made significant contributions to Analytical Chemistry. Costachescu in the fields of the utilization of natural resources, salt composition, correlation of salt-oil-deposition; and in coordination compounds, of which he was the founder in Romania. Cernatescu researched on new reactions for determination of nitric acid, nitrates, molybdates, vanadates, alkaloids, as well as for cations, including silver, cadmium, magnesium, and copper; he also contributed to the development of polarography.

For a long period, at Universities in Jassy, Bucharest, Cluj-Napoca, inorganic and analytical chemistry came under the same Chair/Department; this was for the benefit of Analytical Chemistry at that time, because the developments in the research in inorganic chemistry influenced very much the developments of highly sensitive detection of e.g., metals. Further developments and pioneering in coordination chemistry lead to improvements of the limits of determination to micro levels.

\section{The rise of instrumental techniques in the twentieth century}

Developments of instrumental techniques have made a major impact on public health and welfare and on the development of a modern chemical industry in Romania [29].

The first important step in the instrumental techniques was that by $\mathrm{N}$ Teclu in the 19th Century, in his studies of flame characteristics; the burner built by him in 1892, it is still in daily use in the laboratories worldwide. He also made pioneering studies in flame photometry and flame transparency [2].

The first professor (that stage in Inorganic Chemistry) of the Faculty of Sciences, University of Bucharest to perform research in Analytical Chemistry was GG Longinescu (1906-1938) [31]. His team contributions were in: separation and identification of elements in the hydrogen sulphide group (the main researchers in this direction being G. Chaborschi, E. Petrescu, G. Theodorescu); separation, identification, and determination of halogenated acids (with contributions of G. Chaborschi, Th. Pirtea, M. Badescu); identification reactions for different ions (with the main contribution of G. Chaborschi, E. Petrescu, Th. Pirtea). Longinescu wrote the first Romanian textbook on quantitative analysis for students [32].

The contributions of Professor Gheorghe Spacu to Analytical Chemistry were of high importance achieved by building two strong teams on Analytical Chemistry, first in Cluj-Napoca from 1919 and 
from 1940 in Bucharest. His teams contributed to both qualitative and quantitative analysis by evolving new reactions and reagents [27]. Work published by him with the team in Cluj included Raluca Ripan, L. Caton, E. Voicu, C. Creanga, T. Dick, G. Suciu, I.G. Murgulescu, C.G. Macarovici, V. Armeanu, Petre Spacu, E. Popper, P. Voichescu, M. Vancea, C. Dragulescu, C. Dima, A. Pop, V. Nicolescu and M. Kuros, all of whom became well known and founders of schools in inorganic or/and analytical chemistry. Their work was mainly based on formation of insoluble coordination compounds facilitating the identification and assay of a large number of metals, acids and various organic materials [27]. The gravimetric and potentiometric techniques for the assay of the $\mathrm{Cu}(\mathrm{II})$, $\mathrm{Ni}(\mathrm{II}), \mathrm{Co}(\mathrm{II}), \mathrm{Cd}(\mathrm{II})$ ions developed by Spacu with his co-workers involving pyridine, aniline, benzidine, ethylenediamine facilitated determination at microgram levels [27]. Beginning with 1922, Gheorghe Spacu published a series of new gravimetric methods permitting the weighing of precipitates immediately after drying in vacuum. Coordination compounds with two mixed ligands (e.g., the coordination compound of copper with pyridine and sulfocyanide) are used, even today, for gravimetric, volumetric or spectrophotometric determinations of certain elements; using this technique, semi-microanalysis could be performed for metals such as zinc, cobalt, nickel, manganese. One of the most important methods of analysis developed by his group, in Cluj-Napoca was that for mercury using the weight of $\left[\mathrm{HgI}_{4}\right]\left[\mathrm{Cu}(\mathrm{en})_{2}\right]$ after drying in vacuum [27].

IG Murgulescu's contributions to Analytical Chemistry were mainly on development of new methods for the assay of metals by using absorption indicators and redox agents in volumetric analysis, and using conductometric techniques. Together with Coriolan Dragulescu, he introduced several physical-chemical techniques as methods of analysis, starting a new era, instrumental methods of analysis. Ion Atanasiu was the founder of the Romanian School of Electrochemistry, known for innovations in the use of cerium (IV) as a titration reagent.

An important contribution to the instrumental analysis of organic compounds was the one of Eugen I. Angelescu; he did study the relation between the structure and physical properties of organic compounds.

Raluca Ripan's main field on chemical analysis was the research on coordination compounds and their applications in Analytical Chemistry. She developed new methods used for the assay of thallium, lead, tellurium, selenic acid, selenocyanates, to mention a few. She was the first women elected as full member of the Romanian Academy. At Cluj-Napoca she created an active school of Analytical Chemistry, also training students. These included, Candid Liteanu (who later on was recognized for his research in chromatography and chemometrics), Al. Duca (feature head of the Department of Analytical Chemistry in Jassy), and Grigore Popa (feature head of the Department of Analytical Chemistry in Bucharest) [27].

C.G. Macarovici, professor at Cluj-Napoca, main topics were the determination of zinc, copper, cobalt, and nickel and studies on amine complexes.

One of great successes achieved by Spacu in 1933 together with E. Popper was in the field of molecular refraction and refractometric analysis.

C Dragulescu (Head of Department of Inorganic Analytical Chemistry) in the Polytechnic Institute in Timisoara used potentiometric methods to determine metals and acid radicals (e.g., tin, bismuth, arsenates, sulphites). In Timisoara, great contributions to the Analytical Chemistry were by Constantin Candea, in the following fields: separation of copper group metals, separation of the acidic sulphides in qualitative analysis. One of the main representatives of Analytical Chemistry in Timisoara was D. Ceausescu with important contributions in the field of chemometrics.

In Jassy, Margareta Poni, R. Ralea and Simon Fisel contributed to polarography, kinetics, chromatography, colorimetric analysis.

Fast developments of industries, after 1944, were very much influenced the developments in Analytical Chemistry [29]. Specialised analytical laboratories were then established by the large factories, and many analytical chemists were employed for both research in Analytical Chemistry and in routine analysis. As a consequence, many University Departments of Analytical Chemistry 
developed by splitting the Departments of Inorganic and Analytical Chemistry.

In 1960, the first Department of Analytical Chemistry at the University of Bucharest was set up, From the many researches performed one can only mention main studies such as those on organic reagents for the assay of metallic ions, on the stability of coordination compounds in different solvents for the assay of metallic ions. Using pyrazolinic derivatives, e.g., tartrazine, flavarine L, George-Emil Baiulescu developed new gravimetric, amperometric, and spectrophotometric methods for the analysis of zirconium, hafnium, palladium, beryllium, molybdenum and new spectrophotometric methods for the assay of palladium and uranium. A special field of the determination of equilibrium constants of coordination compounds was born by performing numerous studies on ionic equilibria in aqueous and non-aqueous solutions, using electrometric and spectrophotometric methods. Di-2-ethyl-hexyl-phosphoric acid and its salts were used as stationary phases for the separation of chlorinated derivatives of benzene.

In 1964, the University in Cluj-Napoca founded its Department of Analytical Chemistry; the main research areas were chelatometric titrations, determination of equivalence points in titrimetric methods, chemometrics, frequentometric analysis, and ion-selective membrane electrodes with membrane made from polymer plasticiser membranes, precipitate impregnated membranes, and ceramic membranes. Radiometric and radiochemical methods of analysis developed in Cluj by Gheorghe Marcu and co-workers and in the Institute of Nuclear Physics in Bucharest by the team of T. Nascutiu. At Cluj-Napoca, the most significant contributions to the development of analytical chemistry were by Professor Candin Liteanu, who studied several branches of analytical chemistry, such as titrimetry, chemometrics and theory of detection, separation sciences and sensors. Some of his books that cover important topics in Analytical Chemistry are still useful for the analysts [33, 34].

In Jassy, the main directions in research were solvent extraction, chromatography, and spectrophotometry. Timisoara's Department of Analytical Chemistry became known through its development of new organic reagents for chemical analysis and separation methods using solvent extraction and ion exchange techniques.

DN Todor published a study on the thermal analysis methods - dedicated to rocks and minerals.

Analytical Chemistry hold a key role in quality control in industry, and therefore institutes of research with the primary aim of quality control were build (Institute of Chemical Research Bucharest, Chemical Pharmaceutical Research Center - Bucharest; Institute for Nonferrous and Rare Metals - Bucharest; "Petrochim" Institute - Ploiesti; "Chimigaz" Institute of Medias). All these institutes had highly qualified researchers, and the best instrumentation for research.

Before World War II the available instrumentation used had limited performances, after 1960, the laboratories were equipped with modern instrumentation such as: gas chromatographs, atomic absorption spectrophotometers, X-ray fluorescence spectrophotometers, mass spectrometers, spark mass spectrometers, and electron probe microanalysis instrumentation. The need for high quality products was important to introducing automated methods of analysis for process control.

The field of Ion-selective membrane electrodes developed very quickly in Romania due to the contributions of Vasile V. Cosofret and George-Emil Baiulescu. In 1977, they published a book focused on their applications in organic analysis [35], it was translated later into Russian in 1980 (Mir-Moscow publishing house). Later on, Vasile V. Cosofret published alone a second book on the ion-selective membrane electrodes with applications in pharmaceutical analysis [36]; a third book of Cosofret was co-authored with Richard P Buck [36].

Developments in the research on chromatography are shown not only by the publications in various specialized journals, but also by the books such as that published by VA Ilie and GE Baiulescu dealing with stationary phases in gas-chromatography [38].

Sampling has always been considered the key for a successful analysis and for this reason GE Baiulescu together with P. Dumitrescu and P. Gh. Zugravescu wrote a book focused on this part an analytical process [39], which was translated in Chinese in 1996. 
Educationalists in Analytical Chemistry placed their main role the provision at the highest level of young researchers able to continue the pioneering work of their mentors. Over the years, many textbooks have been written for the use of undergraduates in Romania, such as that on semimicroanalysis by R. Ripan, E. Popper, and C. Liteanu [40], or for quantitative chemical analysis with organic reagents, written by G. Popa and S. Moldoveanu [41]. A significant contribution was a series of seven volumes on physical chemical methods of analysis, and four volumes on separation methods (supervised by George-Emil Baiulescu) published by the Documentation Centre of the Chemical and Oil Industries. G.E. Baiulescu, C. Patroescu, and R.A. Chalmers emphasized the necessity of new courses and approaches for teaching analytical chemistry in a valuable and influential book, in 1982, and translated in Chinese in 1993 [42].

"Chimia Analitica" was the first Romanian journal in the field of Analytical Chemistry. Published first in 1971, it comprised original papers, applications for industries, and book reviews. The journal facilitated the transfer of knowledge between different groups working in Analytical Chemistry in the country. "Revista de Chimie", a journal of the Romanian Society of Chemistry and "Revue Romain de Chimie", a journal of the Romanian Academy also contain several articles on Analytical Chemistry.

International conferences became important to Romanian chemists who followed George-Emil Baiulescu's lead. He used to say, the best way to get informed about the achievements in Analytical Chemistry is direct information, Romania held three National Conferences with international participation, the International Union of Pure and Applied Chemistry [44] sponsored the last. On these occasions prestigious analytical chemists were invited, e.g., I.P. Alimarin, R. Belcher, G. Charlot, R. Chalmers, H. Laitinen, E. Pungor, G. Valensi. In the 90's the series of National Conferences on Analytical Chemistry were restarted, after the Society of Analytical Chemistry from Romania (SCAR) was established. Conferences have been held in Jassy, Cluj-Napoca, Constanta, Piatra Neamt, Brasov, Timisoara, every 2nd year and had numerous distinguished participants from abroad, great names in Analytical Chemistry like RP Buck, E Pungor, L Niinisto, F Adams, HY Aboul-Enein, JF van Staden, YA Zolotov.

Societies In 1919, a group of chemists were meeting in the Laboratory of the Department of Analytical Chemistry, of the University of Bucharest to start the society of chemistry, called Romanian Society of Chemistry, now having a Division of Analytical Chemistry [44]. In the '90s, George-Emil Baiulescu started the Society of Analytical Chemistry from Romania abbreviated as SCAR. It has as its logo a rabbit, which he considered the best symbol of an analytical chemist. Saying that analytical chemists are like rabbits, when the results of the analysis are good, the one requesting them has the suspicion that he faked them. When the results of the analysis are not as good as the one requesting the analysis, again it is the fault of the analytical chemist, who did not know how to perform the analysis. Under the umbrella of SCAR there were many very important events. Every month a talk was organized with the main topic Analytical Chemistry, but also other topics such as those connected with beauty of mountains were agreed. A series of conferences was started, prestigious analytical chemists being invited with plenary lectures, on the occasions of such conferences round tables regarding the future of Analytical Chemistry were held. For many years, SCAR has been affiliated to the DAC of EuChemS, being represented in DAC the founder of SCAR: George-Emil Baiulescu [45].

\section{Conclusions}

Over the years, the analysts from Romania have made significant contributions to the development of Analytical Chemistry, many of which have been well recognized among the other analysts in Europe. They developed teaching and research schools in the main universities or research institutes, with numerous achievements that are difficult to be fully covered entirely in a single review. Their researches were integrated into the main trends of research internationally in Analytical Chemistry. Additionally, they made contributions to progress in many other branches of science and technology, such as, 
Biochemistry, Medicine, Agriculture, Geology, Environment, or Chemical Industry.

\section{References}

1. BURNS, D.T., MULLER, R.K., SALZER, R., WERNER, G., Important Figures of Analytical Chemistry from Germany in Brief Biographies: From the Middle Ages to the Twentieth Century. Heidelberg: Springer, 2015.

2. BAIULESCU, G.E., MOLDOVEANU, S., WEST, T.S., Nicolae Teclu (1839-1916), A pioneer of flame spectroscopy, Talanta, 30, 1983, p.135-137.

3.POPA, G. The development of analytical chemistry in Romania, Pure Appl. Chem., 31, 1972, p.447454.

4.OlARIU, A., BESliU, C., BELC, M., POPERCU, I.V., BRADICA, T., LAZATOVICI, G., Compositional studies of ancient copper from Romanian territories. J. Radioanalyt Nuclear Chem., 243, 2000, p.599-605.

5. MARUTOIU, C., BRATU, I., TRIFA, A., BOTIS, M., MARUTOIU, V.C., FTIR analysis of painting materials from the Church of Saint Paraschiva, of Pioenile Izei, Maramureş, Romania, Int. J. Conserve Sci., 2, 2011, p.29-34.

6. BUGOI, R., TALMATCHI, C., HAITA, C., CECCATO, D., Archaeometric studies of Byzantine pottery from Hârşova-Carsium, Nucl. Intr. Method Physics Res. B., 348, 2015, p.296-301.

7.POPA-GORJANU, C. Transylvanian identities in the Middle Ages in F. Sabate (ed.). Identitats. Lleida: Reunion Cientifica, 2012, p.175- 190.

8.WILSON, W.J., Catalogue of Latin and vernacular alchemical manuscripts in the United States and Canada. Osiris. 6, 1939, p.1-836.

9.KISS, F.G., LANG, B., POPA-GORJANU, C., The Alchemical Mass of Nicolaus Melchior Cibinensis: Text, Identity and Speculations, Ambix, 53, 2006, p.143-159.

10.MAIER, M., Symbola aurae mensae duodecim narionum, A. Hummius: Frankfurt, 1617, p. 509.

11.SHERWOOD, T.F., JOSTEN, C.H., Johannes. Banfi Hunyades 1576-1650, Ambix, 5, 1953, p.44-52 and p.115.

12.GOMORI, G., New information on Janos Banfihunyadi’s life, Ambix, 24, 1977, p.170-174.

13.APPLEBY, J.H., Arthur Dee and Johannes Bánfi Hunyades: Further information on their alchemical and professional activities, Ambix, 24, 1977, p.96-109.

14.ROSCA, S., Ungureanu, M.E. Societatea de Chimie din Romania la 100 de ani de la constituire. Bul Soc Chim din Romania, XXVI, 2019, p.4-14.

15.RADY, M., A Transylvanian alchemist in seventeenth-century London, SEER, 72, 1994, p.140-151. 16. CANTEMIR, D., Mic compendiu asupra întregii învăţături a logicii, intro. Alexandru Surdu, trans. Dan Slusanschi, Bucharest: Editura Ştiinţifică, 1995

17.***Anon. Inquiries for Hungary and Transylvania, Phil. Trans. R. Soc., 2, 1666, p.467-473.

18. BROWN, T., Some Directions and Inquiries with their Answers, Concerning the Mines, Minerals, Baths \&c. of Hungary, Transylvania, Austria, and other Countries neighbouring to those, Phil. Trans. $R$. Soc., 5, 1670, p.1189-1196.

19.BURNETT, G., (written to T.H.R.B.) Some letters containing an account of what seemed most remarkable in travelling through Switzerland, Italy some parts of Germany, etc. Rotterdam: A. Acher; 1686.

20. KAZMER, M. Carpathian minerals in the eighteenth-century Woodwardian collection at Cambridge, J Hist Collec., 10, 1998, p.159-168.

21. WILKINSON, R.S., The Hartlib papers and seventeenth-century chemistry, Ambix, 15, 1968, p.5469.

22.HUNTER, M., CLERICUZIO, A., PRINCIPE, L.M., The Correspondence of Robert Boyle. London: Pickering \& Chatto; 2001. Hartlib to Boyle pp.158, 172,176, 229-230, 232 and 252, Brun to Boyle, pp.163-165 (from London, re cures for kidney stone) and 187-188 (from Cork, re assistance with a supply of chemicals). 
23. MADDISON, R.E.W., The Life of the Honourable Robert Boyle FRS. London: Taylor \& Francis; 1969. p. 67ff.

24. KOLERESI, S., De Keres-eer, Secretarrii Gubernialis Cæsareo-Regii, Principatisus Transyilvaniæ, Auraria Romano-Dacia, Cibinii, M. DCC. XVII.

25. *** On-line, Records at the Royal Society, London.

26. WEEKS, M.E., The discovery of the elements. VI. Tellurium and selenium. J. Chem. Educ., 9, 1932, p.474-485.

27. BAIULESCU, G.E., Analytical Chemistry in Romania, Anal. Lett., 5, 1972, p.581-587.

28. FEIER, V., BRINZEU, D.T., FEIER, L., Medical relationships between Moldavia and the Banat in the 10th and the 20th centuries, Rev. Med. Chir. Soc. Med. Nat. lasi, 111, 2007, p.783-788.

29. FLORESCU, M., The role of analytical chemistry in the development of modern chemical industry, Pure App. Chem., 31, 1972, p.433-445.

30. *** Obituary notices, Stefan Minovici, J Chem Soc., 1938; p.161-163.

31.RADU, G.L., BAIULESCU, G.E., The beginings of A. C. in Romania, Fresenius J. Anal. Chem., 357, 1997, p.189-190.

32.LONGINESCU, G.G., Analiza calitativă. Bucureşti: Editura Copuzeanu; 1929.

33.LITEANU, C., GOCAN, S., Gradient Liquid Cromatography. Chichester: Ellis Horwood; 1974

34.LITEANU, C., RICA, I., Statistical Theory and Metodology of Trace Analysis. Chichester: Ellis Horwood; 1980.

35. BAIULESCU, G.G., COSOFRET, V.V. Applications of Ion-Selective Membrane Electrodes in Organic Analysis. Chichester: Ellis Horwood; 1977.

36.COSOFRET, V.V., Membrane Electrodes in Drug-Substances Analysis. Oxford: Pergamon Press; 1982.

37. COSOFRET, V.V., BUCK, R.P., Pharmaceutical Applications of Membrane Sensors, CRC Press, Boca Raton, 1992.

38. BAIULESCU, G.E., ILIE, V. Stationary Phases in Gas Chromatography. Oxford: Pergamon Press; 1975.

39.BAIUlESCU, G.E., DUMITRESCU, P., ZUGRAVESCU, P.Gh., Sampling. Chichester: Ellis Horwood; 1991.

40. RIPAN, R., POPPER, E., Liteanu C., Chimie analitică calitativă. Semimicroanaliza. Bucuresti: Editura Tehnică; 1954 (first edition); 1963 (fourth edition).

41. POPA, G., MODOVEANU, S., Analiza Chimica Cantitativa cu Reactivi Organici. Bucuresti: Ed. Tehnica; 1969.

42.BAiUlesCU, G.E., PATROESCU, C., Chalmers R.A., Education and Teaching in Analytical Chemistry. Chichester: Ellis Horwood; 1982.

43.***Pure and Applied Chemistry, 1972; 31: issue 4, 433-578. Third National Conference on Analytical Chemistry, Brasov, Romania, 22-26 September 1971

44.DAVID, V., 50 years of analytical chemistry at the University of Bucharest, Analele Univ Burcuresti, 20, 2011; p.5-8.

45.THOMAS, J.D.R. An analytical chemist of verve: George-Emil Baiulescu, Talanta, 44, 1997, p.1501-1504.

Manuscript received: 22.01 .2021 